United States Department of Agriculture

Agricultural Research Administration

Bureau of Entomolozy and Plant Quarantine

A REVIEW OF INFORMATION ON ANABASINE AND NORNICOTINE, 1933-1944

(Supplement to E-537 and E-561)

By R. C. Roark, Division of Insecticide Investigations

CONTENTS

Page

Introduction .................... 2

Chomistry of anabasine ................. 2

Occurrence of anabasine and nornicotine ....... 3

Snabar 18 .................. 3

Dub0181a ...................... 3

Sicotiane ..................... 3

Occurrence of nornicotine in commerclal nicotine

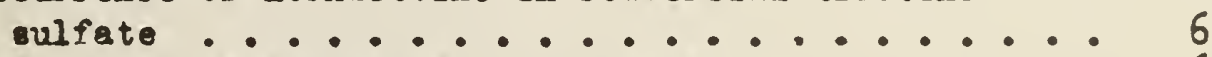

ixtraction of anabasine from plants ........ 6

Composition of commerclal anabasine sulfate made from

Anabar18 .................. 7

Analytical methods ............... 7

Separation of anabasine from nlcotine and other

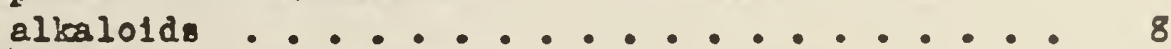

Pharmacology of anabasine and nornicotine ...... 11

Anabasine .................. 11

Sornicotine ................. 11

Insectlcldal value of anabasine ........... 12

Thysanoptera ................. 12

Homoptera . . . . . . . . . . . . . 13

Homlptera ................. 14

Dlptera ........................ 14

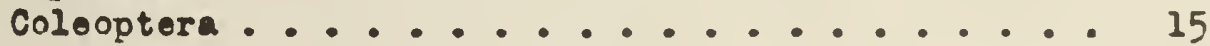

Anoplura ........................ 15

Patent. . . . . . . . . . . . . . . 15

Ilterature clted ................. 16 


\section{INTRODJCTI ON}

In April 1941 the Bureau of Entomology and Plant Quarantine issued B-537, A Revion of Information on Anabasine, and in March $1942 \mathrm{~B}-561$, A Reviow of Information on Nornicotine. These reflewed 163 and 50 publications, respectively. The purpose of the present publioation is to bring. up to date all available information on both these promising insecticides.

In preparing this review the following abstract jouraals, published from 1938 to 1943, inclusive, were searchod: Biological Abstracts, Chemic2l Abstract, Chemisches Zentralblatt, Reperiment Station Record, Inder Medious, and Review of Applied Entomology (Series $A$ and B). In addition the Quarterly Bibliography on Insecticide Naterials of Vegetable Origin through No. 26 (January to March 1944), issued by the [Great Britain] Imperial Institute Consultative Committeo on Insecticide Haterials of Vegetable Origin, was consulted.

\section{CHENISTRY OF ANABASINE}

The following constants for anabasine are given: Boiling point $(\mathrm{p}=$ $238 \mathrm{~mm}$ ) $280.9^{\circ} \mathrm{C}$, , freezing point $9^{\circ}$, specific rotation $-33.1^{\circ}$. Its parachor coincides closely with the theoretical parachor.-- Sokolov (75).

In a report on the reactions of amino-n-methylanabasines the follow ing melting points are given:

$$
\begin{array}{cr}
\text { alpha-Amino-iN-methylanabasine } & 95-95.3 \\
\text { Derivatives: } & 72-73 \\
\text { Acetyl } & -60.5-62.5 \\
\text { Diacetyl, hydrate } & 91.5-92.3 \\
\text { alpha'-Amino-N-nethylanabasine } & 122-122.5 \\
\text { Derivatives: } & 97-98 \\
\text { Acetyl } & 104-106 \\
\text { Propionyl } & 142-145 \\
\text { Benzoyl } &
\end{array}
$$

The plerate of the alphe compound decomposes at $238-239.5^{\circ}$, and that of the alpha' compound at $227.5-228^{\circ}$. The boling point of the diacetyl derivative is $160-162^{\circ}(p=4 \mathrm{~mm})$, and that of propionyl derivative $\left(p=5.5\right.$ mo) $193-200^{\circ}$ - Kabachnik and zits or (32).

The dihydrochloride of dichloroanabasine is obtained by passing chlorine into anabasine in cold alcohol. The yield is 29-63 percent. It melts at $203.7^{\circ} \mathrm{C}$. (dec.) Free dichloroanabasine dissolves in water with difficulty, is soluble in othyl aloohol, slightly less solublo in other, and melts ot $51-3^{\circ}$. It reacts with picrio acid, forming a picrat, 
melting at $91-5^{\circ}$. Nicotinic acid is formed by oxidizing dichloroanabasine with a permanganate solution. Bromination of anabasine under the same conditions forms bromo-subst1tuted compounds, melting at $105^{\circ}$ and $135^{\circ}$, which are very hygroscopic and very unstable. At 80-100 they are decomposed by water with the separation of anabasine. The amount of bromine decreases considerably on prolonged keeping of the bromo-substituted compounds. The picrate of one bromo-sinbstituted compound melts at 199-201\%, and according to 1 ts bromine content it corresponds to a monobromosnabasine.- nashkevich (20).

\section{OCCURRIMTE OF ANABASINT AND NORHICOTINE}

The most important sources of anabasine are the tree tobacco, Nicotiana glauca, a native of Argentina and Uruguay, and the Russian shrub, Anabasis aphvila, which is related to the American tumbleweed. Although $\mathrm{N}$. glauca is a native of South America, it $1 \mathrm{~s}$ very much at home in Mexico and in the gouthwestern United States.... Higbee (27).

$\triangle$ review of information on anabasine discusses sources, chemlstry, alkaloids of Anabasis aphylla, physiological action, insecticidal properties, and commercial forms used for pest control..- Holman (28, pp. 21-25).

A comprehengive review on the alkalolds of tobacco includes nornicotine and anabas ine.- Jackson (31).

\section{Anabasis}

The anabasine content of Anabasis aphylla was found to be inversely proportional to the degree of moisture. However, this relationship cannot be accepted as an absolute rule without further verifications.-Kudryarteer $(\underline{34})$.

Anabasis aphylla contains anababine, lupinine, aphyllidine, and aphyline. The preparation of salts and other derivatives is described. Anabasine, upon reacting with bolling 5-percent hydrochlorlc acid, undergoos ring opening. - Spath, Gelinorsky, and Mayer (82).

In a study of saline plants of Turkmania Anabas is aphylla was found to contain 2 percent (dry basis) of potassium nitrate.- Sabinin, Baslavakaja, Beloussova, and schocklender $(\underline{60})$.

Duboisia

Analyses of samples of Dubolsia hopwood11.received from Australia showed nornicotine to be the only alkalold present, as follows: Leaves 3.31, leaves on twigs 1.92 , twigs without leaves 0.95 , and larger stems 0.52 percent.-- Bowen (10).

\section{Nicotiana}

From the steam-volatile fraction of extracts of cured tobacco leaves, rolatile bases other than nicotine amounting to at least 6.5 percent of the total alkaloid content were obtained. The diplcrate of a base 18olated from this nornicotine fraction decomposed at $179.5-180.5^{\circ} \mathrm{C}$. (uncor.). This base reacted with nitrous acid and with benzoyl chloride in the manner described by Pictet and Rotschy (ref. 30 in E-561) for nicotimine..Vickery and Pucher (85).

The rolatile and nonvolatile alkaloid contents of the following species of Nicotiana are given: acuminata, alata, chinensis, glauca, glutinosa, langs- 
Jorffi, longiflore, Daniclleta, Dumbaginifolize, quadrivalvis, repanda, msovi, ristica, sander e, swaveolens, sylvestris, tabacum. The alkajoid content of a number of hyorids is given.-- Shmuk and Khmura (68).

Nicotiana tabacum normally contains nicotine but no anabasine, whereas N. glauce contains only anabesine. When $\mathbb{N}$. Elauca was grefted on $\mathbb{N}$.tabacum, formation of the characteristic alkaloid proceeded in stock and scion with a consiceraole increase in the anabasine content of the scion over that of the control plant. Anabasine aoveared to be formed in the stock also. When N. tabecum ares grafted on N. Llauca, nicotine was completely replaced by anabesine in the scion while a trace of nicotine appeared in the stock.-Shmuk, Kostor, and Borozdina (óg).

When Nicotiana rustice was grafted to $\mathrm{N}$. gleuca, it lost nicotine and accumuleteri anabe sine.-- Sinnuk (

The erafting of nicotine-cortailing tobacco on the nicotine-free soecies, Nicotiana glauca, resulted in olants in which the nicotine was completely renlaced. oy anabasine.-- Evtusinenko (a

A study was made of the inieritance of nicotine and ansbasine content oy Nicotiana tabacum $x$ Nicotiana glauca hybrids, and interaction of stock and scion when these species are grafted. In hyurids a change was noted in the type of $\varepsilon$ lkalnids with reference to position of the leaves.-Kuz'menko and Tiknvinskaya (35).

Nornicotine was identified in the following species of Nicotiana: benthemiana, ingulba, lonfiflora, palmeri, sanguinea, solanifolia, suaveolens, silvestris, and trigonophyl la. -- Shruk (ó 4 .

A large aluber of renresentative Nicotiana species end hyorids vere examiner for alkaloids. All 29 of the wild soecies contained 1 or more alkaloids. N. Elata, bigelovii, gossei, and wikendioldes apparently conteined only ninotine. N. glutinoca, maritimo, otonhora, tomentosa, and trieonophyl la aoparently contained only nornicotine. ‥ debneyi and glauce contained larkely $\underline{d}, \underline{l}$-anabasine. In debneyl about 15 oercent of the total alkaloid was nicotine, whereas in glauca a much lower percentage of this alkaloir wes found. The remaining 18 species contained mixtures of nicotine and nornicotine. Nicotine was predominant only in $N$. benavidesil, langsdorffi, and stocktoni; in longiflora and plumoaginifolia it was not possible to determine which of the two alkaloias was present in tie higher concentration; and in the rest nornicotine predominatej. No wild species studied hed as much as 2 percent total alkaloid content, and most species had less than 0.5 percent. In 23 species 84 to 100 percent of the total alkaioid content was taken up by the nain alkaloid. In crosses between $N$. tabacum, wich contains mostly njcotine, one species whose alkaloid coulex was made up largely or entirely of nornicotine, the hyorids contained mainly nornicotine, together with small amounts of nicotine. The $F_{1}$ and anohidiploid N. tabacum (nicotine) $x$ N. glauca (ancivesine) contained mostly anabasine with some nicotine. In one sćnple of tuis $F_{1}$ a trace of nornicotine was detected.-- H. H. Smith হnत C. R. Smith (74).

A method is presented for classifying tobecco broadly into three trpes accoraing to their picrate melting points-- (I) the 
nicotine type, $275-224^{\circ} \mathrm{C} . ;$ (2) the mixed type, 190-215 , indicative of both $2.1 \mathrm{kaloi}$ s $8 \mathrm{~s}$ mafor components; and (3) the nomicotine type, 175-200\% Of 90 smmples of tobacco examined, 2 were of the nornicotine type. One, Robinson's l?aryland Medium Broadleaf, was investigated by liarkwood (refs. 25 and 26 in E-561), the other, Flue-cured Cash, may prove equaliy valuable as a source material of nornicotine. Two tobaccos were of the mixed type; the others were of the nicotine type.-- Markmood and Barthel (46).

The 42 species of Nicotiana, when analyzed by an improved prooedure wich is described, can be divided into 4 roups as follows: (1) The nain alkaloid is nicotine, secondary pyridine alkaloids being absent or present only in insinificant quantities; (2) the main alkaloid is nornicotine, tertiary pyridino alkaloids being absent or present only in insionificant quantities; (3) a mixture of nicotine and nornicotine, and (4) the main alkaloid is anabasine. - Shmuk and Borozdina (67).

A simplified method is presented for the identification of alkaloids of tobacco. The essence of the rethod is the formation of the picrates of the secondary base and submission of it to methylation without isolation of the pure awine; for effectiveness it is sufficient to have 2 to $10 \mathrm{mg}$. of the alikaloid. The picrate of the base is methylated quantitatively by heating with formaldehyde and formic acid. The presence of nornicotine by this procedure was show in various members of the tobacco family. Determination of the picrate melting point both before and after methylation enabled the nornicotine to be identifisd in the presence of nicotine. Anabasine and piperidine are also methylated by this procedure.-- Shmuk (64).

In order to find a more lopical basis for a classification of tobaccos, the melting points of picrates prepared from knom mixtures of nicotine and nornicotine were determined. The steamvolatile alkaloids were separated from the plant meterial by dist1llation and the melting point of the mixed picrates of the alkaloids was compared with that of the known-mixture picrates. In the curve prepared from the know-mixture-picrate melting points and composition the slope of the right-hand side was sufficient to warrant establishment of a division at composition two-thirds niootine and one-third norniootine, and temperature $211^{\circ} \mathrm{C}$. Hence, tobaccos, the alkaloids of which give a picrate with the upper limit of the melting range above this point, are considered as the "nicotine type." The division point at composition one-third nicotine and two-thirds nornicotine, and temperature $196^{\circ} \mathrm{C}$, falls in a region of merked discontinuity of melting-point behavior and is therefore even more suitable to set off the "nornicotine typen of tobacco. This leaves the interval $196^{\circ}$ to $211^{\circ} \mathrm{C} .98$ characteristio of "mixed type" of tobacoo. Tobacoos were analyzod for nicotine and nornicotine, and the analysis and the melting point of the piorate of the steam-volatile alkaloids from the sample were compared with the oomposition-melting point curve. The close agreement of the relative peroentage compositions and melting points obtained from the tobacco samples with tiose of known solutions has been used with considerable success in extimating the relativo composition of these alkaloids in samples.-- Sowen and Barthel (15). 
Nornicotine may be identified in tobacco, insecticidal tobacco prenarations, and nicotine oreparations by comparing the melting point of the mixed picrates of the steam-volatile alkaloids with the picrate melting point of a methylated sample thereof. Sethylation of the nornicotine gives nicotine; consequentiy, the picrate of the methylated alkaloids will melt at the same point as nicotine picrate and no depression of melting will occur in a mixed-melting-point determination with nicotine picrate in those cases where steam-volatile alkaloids other than nicotine anc nornicotine are substantially absent.--Bowen and Barthel (16).

When nightshade (Solanum nigrum) Ditura stramonium, and tomato plants, usually free of nicotine, were grafted separately on tobacco (Nicotiana tabacun and N.rustica), they were enabled to form this alkaloid and store it in the leaves and fruit. Iarge quantities of nicotine will form in the scions, if the leaves are removed from the tobacco stock at the time of intensive growth of the scions and the root of tobacco is oresent. When tobacco is used as the scion in graft upon the same olants, nicotine disappears entirely from the Eraft system and cannot be detected in the stock or scion. When $N$. Flauca, which contains anabasine, was grafted on a tomato ylant, $\overrightarrow{a s}$ much anabasine was formed by the scion as occurred in the control plant of $\mathrm{N}$. Elauca raised under normal conditions..-Shmuk, Smirnov, and II'in $(70)$.

\section{OCCURRENCE OF NORNICOTINE IN COMNERCIAL NICOTINE SULFATE}

Two commerciel samples of nicotine sulfate were found to contain nornicotine, in one amounting to nearly 12 percent of the alkaloid content. This finding is important because nornicotine has been reported to be more toxic than nicotine to aphids. Commercial nicotine preparations containing nornicotine may be expected to be better contact insecticides than those of pure nicotine. Since nornicotine is known to be less volatile than nicotine, when a mixture of the two is used as a fumigant, the predominant effect is believed to be that of nicotine. The presence of nornicotine in materials considered to be pure nicotine products could easily account for erratic and nonreproducible entomological results.-- Bowen and Barthel (12).

\section{EXTRACTION OF ANABASINE FROY PLANTS}

Steam distillation under pressure can be used to remove anabasine from plant material.-- Sokolor (78).

Of the water-imniscible solvents for the extraction of anabasine, ethylene dichloride is the best for yield and for velocity of extraction. Anabasine combines rapidly with the lmourities in technical ethylene dichloride only during the initial stage of standing, after which anabasine is not decomposed and is only partially transferred to the residue with the slowly separating products of the reaction. The ootimum ratio of solvent to raw material is $2: 1$. A semi-production-scale apparatus and experiments are described.-Sokolov and Trupp (gil). 
The diffusion process of producing anabasine by the waterkerosene method is described. Proteins, which are especially harmful in the further treatant of the alkeloids, are decreased sharply by the presence of sodium chloride. The maximum yiold of the alkalolds was 98 percent. In the countercurrent-diffusion process the averape poriod of extraction depends on the temperature of the water it could be reduced to 20 to 30 minutes..- Sokolor and Demonterik (79).

A report on the produotion of anabasine sulfate from Anabasis aphylla at Tohimkent, U.S.S.R., has boen publishod... Iljin (30).

COMPOSITION OF COLMERCIAL ANABASTNE SULFATE MADE FROM ANABASIS

Commercial anabasine sulfato 30 lution 18 reported to contain 21.52 percent of anabasine, 7.52 percent of lupine, 10.45 percent of aphyllidine and aphylline, 18.19 percent of total sulfates, 1.68 percent of froe sulfuric aoid, and 1.24 peroent of inorganic inpurities..- Dashkevi ah (19).

An improved method for the isolation of Iupinine from commor oial anabasine sulfate solution was devised. The crude alkalold mixture was separated by the Orekhor wothod (ref. 98 in E-537) and distillod in vacuo. The low-boiling fraction $136-90^{\circ}(p=12 \mathrm{mon}$ ) consists of Iupinine and anabasine. The mixture is dissolved in dry toluene and treated with metall10 sollum with stirring and heating. On cooling the sodium lupinate 1s filtered off, washed with dry toluene, and treated with water, the mixture 18 extracted with potroleum ether, and the artraot dried and conoentrated to yield orystalline lupinine (97 percent recovery). The mother liquor after distillation yields anabaibe. The use of petroloum other for washing sodium lupinate also appears to givo a better product than toluene. The best result. were obtained when petroloum other was used as the medium for the reaction with met? ?710 sodium.-. Sadykor and Lozur'ersk11 (61).

In 1935 it was reported that Russia produced 2,500 tons of insecticldes (powders, soaps, and solutions) containing anabasine or ababin oulfate..- Bocharova (8).

\section{Y NATYTICAL METHODS}

A method for the microchemical detection of anabasine in logal chemical investigation has boen desoribed. When Dragendorf's reagent is added to solutions of anabasine, oharaoteristio orystals are obtained which may be used for the microabemioal dotoctlon of the alkaloid in material from the cadaver. In this way as littlo as 1 miorogran of anabasine in a drop of solution can be dotected. The anabasine is extracted from the organs by repoated digestion of the ground material with alcohol to which tartario aold has been added in amounts sufficiont to give an acid reaction to 11twus. The extract is concentrated in vacurm, the protein removed, the aloohol ovaporatod, and the material subjected to pre1iminary purifloation with ohloroform. The tartrate is than converted into the bese by treatment with ammonia, and the bese is extraoted with ohloroform. After removal of the chloroform the anabasine can be tested for direotly, or after further purifioation of the solution.- Shraikova (71). 
A rapid method is proposed for determining totel alkaloids in semimenufactured produots und wasto materials in the production of anabasine. The alkaline extract is extracted with othylene dichloride and the ethylene dichloride extraot titrated with hydroahloric acid (IItmus indicator). For determination in Anabasis the ram material is extracted with water, a part of the water extract is made alkaline, and the analysis conduoted as abore.Sokolor (76).

Separation of anabasine from nlcotine and other alkaloids

A titration method for determining the total alkaloid content of a mixture is proposed which is based on the fact that the acetyl derivative of anabasine does not form a plorate and niootine does.Chmura (33).

Anabasine can be separated from the alkaloids associated with It in Anabasis aphylle by precipitation as fluosilicate from a solution in ethyl or methyl al cohol. The fluosilicate, $\mathrm{C}_{1} \mathrm{H}_{14} \mathrm{H}_{2} \mathrm{H}_{2} \mathrm{~S}_{1} \mathrm{~F}$. $\mathrm{H}_{2} \mathrm{O}, \mathrm{m} \cdot \mathrm{p} \cdot 239^{\circ}\left(\mathrm{deo}_{0}\right)$, can be converted to the free base by reation with sodium hydroxide. Anabasine is preclpitated with alcohollo fluosilicio aold from an alcoholic medium. The precipltate is diseolved in hot water and titrated with a $0.1 \mathrm{~N}$ sodium hydroxide solution (thymolphthalein indicator). Nicotine can be deterwined similarly. Nicotine cen be distinguished from anabasine by the solubility of its fluosilioate in methyl alcohol fluosilicates of both are insoluble in ethyl alcohol.-o Sokolor (75, 77).

A comparative study was made of the reactions of anabasine, nicotine, and coniline. The Meltser reagent (carbon disulfide, othyl alcohol, and dilute coppor alfate solutica) causes a white turbidity with nicotino and a black-brown turbidity with asabasine and conilas. 11 three alkaloid form charaoteristic crystals in saturated aqueous solution of piorio acid. An other solution of anabasine or niootine, when mixed with an other colution of lodine, firat becomes turbid and then orystall1zes. Conline does not undergo this reaction. Hecke reagont (selenic acid and conoentrated eulfurlo ac1d) colore the anabesine residue pink, but does not chenge the oolor of nico

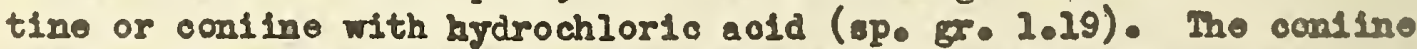
rosidue forms beautifal violet orystals after ovaporation. Io such oryotals are formed from enabesino or nicotine. With nitrie aold (sp. Gr. 1.4) the niootine residue assumes on fion heating a pint oolor, which changer to green. Under the sere conditions no coloration of anabasine and oonilne is observed. A waximu yield up to 95 percont of anabasine alkaloido is obtainod by axtraction of cadaver material with acidified alcohol.-- Raevadoritil (66).

The following directions for determining nlootine in the presence of anabasine are given. Troat the aquoous solution of the alkaloids with $3 \mathrm{ml}$. of 10 -percent oulfurlc acid and $10 \mathrm{ml}$. of freshly preparod 5-percont sodium nitrite, heat for 30 minutes at $40-50^{\circ}$. neatralize approximately by introducing 10-percent sodium hydroxide and then aoourately by titration with $0.1 \mathrm{~N}$ sulfurio soid (with mothyl orange), and add 3 to 4 drops of excess aold. Procipitato the picrates by addition of piario aold (12 por 11ter) and 0001 for 4 hours. Filter, wash twloe with 0.1 -peroent piorio aoid and twice with water, transfor to a glass-stoppered flask, add 16 to 20 
ml. of water, and titrate with a $0.1 \mathrm{~N}$ alkal1 (phonolphthaloin indicator), adding $5 \mathrm{ml}$. of toluene toward the end of titration. The amount of $0.1 \mathrm{~N}$ sodium hydroxide used zultiplied by 0.0081 gives the content of nicotine. The method is based on the fact that nitrous acid, without affeoting the nicotine, transforms the anabasine into the nitroso compound, which is not precipitated by pioric acid under the above conditions..- Shmuk and Borozdine (65).

Nicotine and anabasine, treated with en aqueous solution of aniline and a s-percent solution of amonium thiocyanate or potassium thiooyanate in bromine water, give a yellow color, whioh remain. constant after the addition of 0.5 to $3.0 \mathrm{cc}$. of 5 to 10 percent sodium carbonate for niootine, and changes to a bright rose for anabasibe. The colored solutions can be compared in the colorimeter with corresponding standard solutions. Horevor, the determination of anabasine and nicotine by the colorimetrio method in plants was complicated by the other compounds containing the pyridine ring.-. Shuruk and Borozdina (66).

To identify the alkaloids of to'acco the picrates of nornicotine and anabasine can he methylated quantitatively by henting with formaldehyde-formis acid. Picrio acid does not methylate under the conditions used. Determination of the melting point of the picrate before and after methylation enabled nornicotine to be identified in the presenco of niootino...- Shmuk (64).

Niootine forms an aseotropio mixture with water in a concentration of 2.5 per $100 \mathrm{ml}$. This property is used in soparating it from nornlootine or anabasine, or both. The separation of nicotine from a mixture of the three alkalo1ds was 97 to 103 percent of theory when the prodedure consisted in distilling the mixed alkaloids from $125 \mathrm{ml}$. of water solution through the Fidmer oolum to a low volume (about $15 \mathrm{ml}$ ), adding $60 \mathrm{ml}$. of rater containing $2 \mathrm{gm}$. of sodium ohloride, and continuing again to a volume of $15 \mathrm{ml}$. The combined disth Ilate wa titrated and calculated as nicotine, but represents all the alobtine with some of the accompanying alkaloid or alkaloids. The titrated dist1llate was made alkaline with a slight excess of standard alkall to neutralize the standard acid, and the dist1llation were repeated as before but without the addition of sodium chloride. The oombined distillate was titrated and the niootino oalculated..- C. R. Smith (73).

The determination of niootine and norniootine in the presenco of eech other in aqueous solution is desoribed. One portion of the solution is treated with sodium nitrite and acetic acid. The nitrosonornicotine formed is not volatile in steam from a solution buffered at gil 10. The unchanged niootine 18 steam-distilled off, and determined by acidimetrio titration or by prooipitation with siliootungstio acid. To another portion formaldehyde and formio aold are added to mothylate the norniootine to nicotine. The total alkaloid, now niootino, is distilled of after addition of excess sodiu hydroxide and deternined as before. The difference between the two velues ropresents the nornicotine. Detalls were doveloped for attelning an acouracy of 97 to 98 porcent.-- Markwood (45). 
In improved apparetus for the stoam distillation of nicotine, noraicotino, and subasino has been designed. This apparatur perIf a longer contact between the stesm vapor and the solution oontuining the alkalolde, which results in more rapid distlilation than 1. possible by the conventional (A.O.A.C.) mothod.-- Bowon and Barthol (11).

1 mothod 18 proposed for amlysis of niootine and nornicotine. Sodium chlorido and strong sodium hydroxldo greatly aid the divt1llam tion of norniootine. The stoam distillato containing both alkaloide 10 concentratod, ard an allquant treated with nitrous aold to fore nitrosonoralootine, which 18 not volatilo with otoan under the conditions at which the nfeotine way be distillod (allaline to phonolo phthalein). Precipitation of the silicotungstatos of tho distillato contalning the nicotino and of another allquant containing both albalolds furnishes the moass of calculating the percontages of these albalolds. The results of analyses of several semples of tobscoo, F. rustion, and nomercial nicotine sulfato solutions indloato an unoxpoctodIy जIdospread occurrence of nornicotino. From a comparison of analyses mado aocording to the A. O. A. C. mothod, it is evident that whon nornicotine is present the sooeptod mothod of analysis for nicotine camot be do ponded upon to gito soliable results,- Bowen and Barthel (15).

1 test for the completeness of extraction or alkaloid fran plant material is describod which employs a slight modifloation of the method employod by Markwood and Barthel (800 46) for the I1beration of tho alkaloid from plant material. Aproximately $5 \mathrm{gm}$. of the nare is treatod with $10 \mathrm{ml}$. of atrong sulfurie aold $(9+1)$. whereby the collular struotare is broken down with the formation of the sulfatos of any remaining organjo bacos. Iftor mixing for soveral minutes, wator is addod and the undissolvod portion removod by flltration. The filtrato is noutralised with sodium hydroxide just acidifed with hydrochlorle wold and tostod with illootungstic ac1d solut10a. Tho test solution and roagont are warmod and thon cooled with strong agitation. No procipitato indieater $108 \mathrm{~B}$ thar 0.01 peroent of alootine, norniootine, of anabasin - Bowen and Barthel (14).

1 mothod of detormining nicotino and nornicotino in mixtiuree of tho alkalolds without prolininary soparation is dosoribod. Tho nothed dopends on the reactions of those compounds with oyanogon brealde to give, with nicotine, a palo yollowish-groon color, and it th

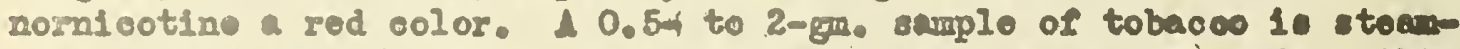
dist1lled from a solution containing salt and sodium hydroxide. The troatment insures a quantitative reoovery of nornicotine, which is maoh 10se volatilo with stoan than is niootino. I volum of the dietillate contalning not more than 80 mierogram of nleotino or 150 miorograns of noraicotine is troatod with potaselum dihydrogen phoaphato, and then with frochly puepued oyanogon bromido roagont. Lftor tho color has boen allowed to devolop, the solution is transforrod to a spootrophotonotor and tho iatonsity of tho color developed by noralootino is read at 540 millindoran and that by nlcotine at 375 millinforone. Concontration of tho albalolin are dotormaned by inspeotion of proviously repogred ealibration ourve. since the oolor developed'by nornlootino has an additive effoot an the intonsity of the oolor givon by niootine, the true concentration of 
nicotine 18 equal to its apjarent concentration tirus the concentration of nornicotine. Factors influencing the development of the colors are discussed.-- Larson and Easg (37).

\section{PEARMACOLOGY OF ANABASINE ALD NORNICOTINE}

Anabasine

Farmers in the Union of South Africa belleved Nicotiana glauca to be deadly to ostriches, and 1t. had been reported to be po1sonous to cattle and sheep. In tests on rabbits the flowers were found to be slightly less torlc than the leares. Rabbits died within 1.5 hours after belng fed $30 \mathrm{gm}$. of the fresh flowers and within half an hour of eatlng the same dosage of fresh leaves. A sheep receiving $300 \mathrm{gm}$. of the fresh leaves through a stomach tube died within 2.5 hours.-- Steyn (84).

Anabasine solutions are fatal to animals-when injected under the skin. Solutions of the equivalent compound anabasine-proto ecid (obtained from soybeans and pee seeds) under the scme conditions causpd only slight polsoning. The rule of Traube stating the relation between the surface tension of a solution and 1 ts polsonous properties cannot be applied to solutions of anabasine-proto ac1d, since in spite of low surface tension such solutions do not kill experimental snimals. Leont'er and Smirnora (39).

Alpha-aminoanabasine possesses the fundamental pharmacological properties of anabasine but 1 s less active. Its depressing act1on on the sympathetic ganglion of white mice is $1 / 75$, its stimulating action on the cerebral loyer and the kldney 1175 , its stimulating action on resplration $1 / 20$ to $1 / 100$, and 1 ts toxic action $1 / 16$. The orimary phase of the depression of respiration is absent; action on the blood pressure of decerebrate cats is less, and production of convulsions in white mice is greater, than wh anabasine.-- Poluektor (54).

The introduction of acetyl, proplonyl, and benzoyl groups in alpha- and alpha'-amino-N-methylanajasine decreases their respiratory stimulation but does not lower their toxic1ty... Kabachnik and 21 tser (32).

The intravenous injection into rabbits of 2.5 to $6 \mathrm{mg}$. of anabaslae sulfate per kilogram of body welght followed by repeated inJections of 0.5 to $1.5 \mathrm{mg}$. Der k1logram caused a decrease in the velocity of blood circulation in the lesser circulation systen. The decrease was due to the action of anabasine sulfate in contraction of the blood vessels and the increased emission of adrenaline.-Pleshchitser (22).

\section{Nornicotine}

On mice and dogs the toxic and vasopressor effects of smoke from a tobacco containing 0.13 percent of nicotine and 0.27 percent of nornicotine were due to the nicotine oresent, and relatively independent of the nornicotine content of the tobacco. On man the smoke from these low-nicotine cigarettes produced much less pronounced ffects on blood pressure and julse rate than did smoke from ordinary c1garettes.-- Haag and Larson (26). 
$A$ omparison hes been made of the toxioity, the blood-pressure offeots, and the fate in animals of leromomicotine, lero-nicotine, monomethylni cotinium lodide, isomonomethylnicotinium lodide, and dimethylniootinium lodide. The integrity of the pyridine nitrogen appears to be essential to the high toxioity of niootine and its mothylated and demothylated derivatives. Progressivo mothylation of the pyrrolidine nitrogen increases the toxicity, as determined by intraperitonoel injeotion in $\mathrm{ml00}$, in the ratio 1:2:4 for nor niootine, nicotine, and monomethylniootinium iodide. Differenco in the dissociation constants of the three bases may be the oxplanation. In dogs the pressor effeots of nornicotine and monomothylnfootinium 10dide are, respoctively, one-twolfth and twothirds those of a moleoulas equivalent of niootine. Isononamethylniootinium lodide and dimethylnicotinium lodide havo praotlcally no pressor cotion. The motabolism, In doge, of the mothylated and demothylated derivative appears tc be different from that of nicotine. No ovidence was found that detoxication of nicotine in the animal body involvo ol ther mothylation or demothylation.Lareon and Haag ( 36 ).

\section{INSECTICIDUL VALUE OF ANABASINB}

Nicotiana tabacum, N. rustion, and N. glauca aro mentionod as poisons for combating animal and plant pesta. Spronger (83).

Dipyridyls testod as contact inseotioldes wore toxdo to $81 x$ spooles of aphids (boan, spinach, por, turnip, applo, and rosy applo). adults and larva of tho colorado potato bootlo, and larve of the threo-lined potato bootlo, the Uediterranean flour moth, and the 81Ikwormo oride dipyridyl oil [now known to have contained some neonleotine or ancbasine] was more toxie than nicotine to certain inseote.- Richardson and smith (58).

The alkalolds of Sophore are intermediato botween anabeino and Iupino. In inseotioldar porrer. Sokolor and Koblove (80).

The results of tosts with anabasine on several speder bolonging to the ordore Thysenoptere, Howoptera, Hemipter, Diptorn, Colooptora, and Inoplura havo been roportod in tho last als yoare.

Thysanoptera

Control moasures for Hellothatp hamorrhoidalis (Bouahe) in Paresia Includod thorough eprayng or the Infosted plant two or throe tines at intervals of 10 dare with 0.6 -peroont niootine sulfats or anabesine sulfate in l-peroont soap solution.-- Voltonke (86).

In Russia spraylag with 7 to $10 \mathrm{~g}$. of anaberin oulfato and $40 \mathrm{gm}$. of soap in 40 litors of water whe offoet1 w against adult thrips on mature Ilex.- Shmelora (62).

4 markod roduotion in infostation by Thrips lint Ind. (11marius Use1) and a oonsiderable inorease in yield of flax ean be obtained Wh a sray contalaing 0.3 or 0.2 peroent of anabacino sulfato in 0.4 -peroont soap solution, or with a dust contalning 5 pereont of anbarino vilfato.-. Ermoloor (21). 
Tree anabasine at $1: 1000$ and $1: 2000$ and anabasine sulfate ( 40 percent anabasine) at $1: 600$ and $1: 800$, with and without sugar, showed high toxlcity to the citrus thrips in laboratory experiments at Whittier, California. Sugar or some other added material 18 probably of value in retarding the 1088 of the toxlc materlal. The thrips do not seem to feed on the anabasine-sugar residues. The material appears to act by contact and by fumigation. Although cltrus thrips do not need to come in contact with the anabasine residue to be killed, the indicated range of the fumigation effect is less than a half-inch. The thrips underwent convulsions, followed by parelJ818, within 9 to 14 minutes after their exposure to anabasine..McGregor (40, 42).

In orchard tests in the San Fernando Valley (Cal1f.) anabasine sulfate $(1: 600)$ with blood albumin gave marked reductions in the strain of citrus thrips resistant to tartar emetic. In similar tests at Wittler anabasine sulfate with sugar and with blood albumin gave high mortalities of the nonresistant strain. No injury to tender lemon leaves was detected from liquid applications of anabasine or anabasine sulfate... McGregor (4I).

Tartar emetic was formerly the perfect control for citrus thrips, but a resistant race of thrips has developed. The best alternative at present is nicotine and sugar, which is satisfactory on lemons. The sulfate 1s superior to the alkalold. Some work bos been done with anabasine, but there is no clear-cut evidence that it is better than nicotine. - Boyce (17).

Anabasine sulfate is recommended for use against thrips attacking flax and hemp in Russia. - N1kiforov (48).

\section{Homoptera}

The toxiclty of andarine wa about equal to that of nicotine agalnet ephlde.-- Froak (23).

An Infugion and a decoction of th leaves of Nicotiana glauca with soap ( 1 pound of leaves to 50 gallons of water) had a very slight effect on nasturtium aphlds, while the powdered leaves had no apparent effect on them. The nlcotine content of the leaves, determined upon a molsture-free bas18, wa only 0.18 percent.-- MeIndoo and S1erer (43) [Thls plant contalne anabaine, not nicotine..R. C. R.]

Anabasine sulfate mixed with beeswax and a fatty oll was one of the material tested at Wenatchee, Wash., in experiments to prevent Briosoma lanigerum (Hausm.) from infosting wound 8 in apple tross. So injury to plant 11 seves reenl ted from the applicat1on, but the effect on the aphlds is not recorded.-. Reeves, Yothers, and Murray (57).

1 spray contalning anabasine valfate ( 40 percent anabisine) at 1 to 1,000 in the elret half of the season on lucerne [Alfalfa], acacia, and cotton infested with (Doral18) Aph1s laburn1 Kalt. and other cotton aphids gave excellent results in the coucrarax- Retrach (56). 
A combination of olbar (barium polysulfide) and anabasino sulfate can be used for the simultanoous destruotion of oucumber milder and aphids. [These materiels will react to form barium

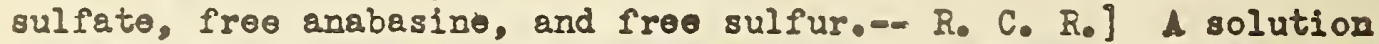
oontaining 0.5 percent of green soap and 0.3 percont of anabasine sulfate killod all the aphids.-. Zubor and Vasilovski (87).

Hemiptere

Concentration-mortality curres are giton for solutions of various nitrogenous bases and soap when applied to the eggs of Lygaeus lcalmi 8tal, and the date are analyzed statistically. The followng median lethal concentrations were obtained: Nicotine 0.11, quinoline 0.12, anabasine 0.18, piperidine 0.29, pyridine 19.6, and sodium oleato 2.0 percent. Quinoline was the only compound that killed the eggs at once. The others permitted development of the embryos to oontimu for several days. In some cases the young bugs were able to emerge from the eggs but died soon after hatching.- C. F. Sinith (72).

Diptera

Of the stomech larvioides tested on Luoilia ouprine Fied. in Lustralia, anabasine sulfate ( 40 percent anabasino) was toxlo at 0.1 percent concentration, whoreas nicotino sulfato was toxio at 0.01 percent. $=0$ Lonnox (38).

In tests by P. M. Petror of sprays against (Yayetiola) Phytophaga destructor (Sey), preparatione of anabasino gave tho best results and wer० effective gainst the eggs.-- Ostapetz (49).

The effects of aerosols of unabasine sulfate and anabasino on Anopheles mosquitoes wore invostigated. The mosquitoes were rery sensitive to anabasine solutions. The minimum lethal dose wes 0.2 m. of anabasine per cuble meter. The aerosol possesses an unpleasant odor, producing coughing, but under summer conditions it is dispersed rapidly and no odor remains aftor 15-20 minutes. To accolerate the reaction at low temperatures the mixture must bo heatod or som dy IIno and bilfurio acid added. Inabasino may bo rolatilized by adding the free base or the sulfato to and hoated to $300-350^{\circ}$. The aerosol had no harmful effoot on rabbits and hens, on the germinating properties of soods, or on food producta.Pogodina and Sokolor (53).

The torioity of anabasine to nosquito larvae was much inferlor to that of niootine.- Froak (23).

The toxioity Indioos of anabasine sulfate (35 poroont anabesine) to Drosophila ampolophila Loew wore dotormined in throe kinds of batto a. Iollows In applo sirup 14.0, in molesses 7.2, and in cano sugar and glycorin 30.7. Sodium arsonite in the respective baits give the following Indioesi 78.6, 62.8, and 63.7.-- Patterson (50). 
In tosts against the eumer oabbage $\mathrm{My}$ in Russia, the percentages of $\operatorname{ggg}$ s destroyed by throo applications of mercurio ohloride (1,1000) wero 95,3, of anabasino sulfato plus groon soap 78.5, and of nleotine sulfate plus soap 76.0. The peroentages of first instars destroyed by these three solutions were, respotivily, 6.61, 2.6, and 3.6. They had no offoot on the second and third Instare.- Galakhor (24).

Then houselly eggs were dipped in an aqueous solution containing 3 percent by wight of anabesine, the mortality was within the same range (0 to 30 percont) as that caused by a solution contalning 5 percont by wolght of niootine.-- Rioherdson (59).

Coleoptere

Rhynohito baochus I., (Coonorrhinus) R. paud11us Gorm., and inthonomus ponoru (L.) aro important pests of fruit troes in Fussia. basting with caloivm arsensto containing 7.5 peroont of anabaino oulfate, or with a proprietazy arsenical (Loritol), at ratos of 13.5 and 27 pounds por acro, respootively, proved offootivo against all three apooles on applo.-. Ibatulin (29).

snoplura

4 solution containing 2 percent of anabasine sulfato and 0.5 persont of groun soap was conplotely effoctive against head 1100 , and had no harmful effect on the scalp.-- PIrovaror (51).

\section{PLTENTS}

dnabseino tamate is made by reacting 17.5 pounds of axabasine and 116 pound of Chinese gallnuts in the presenoe of water. The product is insoluble in water and oontains about 12 peroent of the altaloid. This patont covers the tannates of mothylenabesine and of the misture of alralolds obtalned from Anabasis aphrlia.-o Arnold (1).

Inabasine bontonito 18 ade in the semo way that niootine bontonite 1 mado. Fyening bontonits is treated with an exoess of anbaline sulfato solution. Nfter drying, the produot contains about It percont of the alkalold, of wich ono-balf is wateroluble. Fornieotine bontonito may be made in the seme manner.-. Arnold $(2,4,5,6)$.

Anabesino and norniootine may be substituted for niootine in a dustiag powder wade by volatillsing the alkaloid, usalng it with exhriest gases, and bringing the mixture into contaot with a dust reaponded in gas. suitable Nunfgating and dusting apparatus for troating a troe under a tont are desoribed... Arnold (3).

In insootioldel duot is made by ading from 8 to 20 peroent of froo nabarine or nornicotine to an alkalinired tobacoo dust ar onrior and mixdaf 30 pounds of this with 70 pounds of elas. - Arnold (T). 
aerosol.- Goodhue and Sullivan (25).

Nicotine, anabasine, and nornicotine are among the insectioldes mentionod that can bo used in combination with 2,3-dithiocyano-2,4,4trimethylpentene for pest oontrol, espocially as a fly spray.Bousquet (9).

Derivatives of benzotetronlc acid, including benzotetronic acidalpha-carboxyl10 acld anabaside (made by combining the froe acid and anabasinel, are suitablo insocticides for mothproofing wool.-o Martin (47).

Fatty acids from tung, linseed, flsh, soybean, and other drying 0118 react with nicotine to form water-insolublo, nonvolatile, sticky fluids suitable for insecticide use..- MoKinney (44). [Although no mention is made of anabasine or nornicotine, they could be similarly used.-. R. C. Roark ]

An insecticidal powder is made by mixing anabesine with a highIy dispersible acid clay of limited adsorbing capacity.-- Dashkevich (18).

\section{LITERATURE CITED}

(1) Arnold, R. B. 1933. Now insectioido materiol. U. S. Patent 1,925,225, Sept. 5. To Tobacoo By-Products and Chemlcal Corp.

(2) -- 1940a. Insectloide and process of making the same. U. S. Patent 2,219,287, Oot. 29.

(3) --o 1940b. Method and apparatus for distributing parasticidos. U. S. Patent 2,222,598, Nov. 26 .

(4) -n- 19432. Insect1cide spray materlel and mothod of making the same. J. S. Patent 2,311,629, Feb. 23 .

(5) -..- 1943b. Inseoticidal spray materlal. Canadian Patent 412,635, May 18.

(6) -n- 1944a. Spray material and method of making the same. U. S. Patent 2,343,359, Har. 7 .

(7) … 1944b. Parasiticidal dust for contaot use and process of making the same. U. S. Patent 2,343,360, Mar. 7 .

(8) Bocharova, S. J. 1935. [Results of the work on anabasine.] Selsk. Khoz. Nauka Kazak. (Agr. So1. Kazak). Nos. 1-2, pp. 87-96.

(9) Bousquet, E. W. 1944. Pest control. U. S. Patent 2,342,448, Fob. 22. To E. I. du Pont do Nemours and Co.

(10) Bowen, C. V. 1944. Insecticidal possibilities of Duboisia hopwoodil. (Scientific Note) Jour. Econ. Ent. 37.293. 
(11) -a and Bartbel, W. F. 1943a. Improved team-diet1llat1on apparatus. Indus. and Ingtn. Ches., Analgt. Id. 15: 596, 111us.

(12) -.. and Barthel, W. F. 1943b. Nornlcotine in commercial nlcotine vulat solutlons. (Sclent1lic Sote) Jour. Icon. Int. $36: 627$.

(13) -co and Barthel, T. F. 1943c. Deteralnation of Ilcotin and nornicotine in tobaccos. Indus, and Ingln. Chen., Analyt. Id. 15; 740-741.

(14) -.. and Barthol, K. I. 1944a. Tost for coupletenos of extraction of tobacco alkaloids from plant materials. Assoc. Off. $\triangle$ Br. Chem. Jour. 27 . 224.

(15) -n- and Barthel, K. T. 1944b. Classiflcation of tobacco, nicotinonornicotine mothod. Indus. and Ingin. Chem. 36: $475-477$.

(16) - - and Berthol, W. I. 1944c. Ident1f1cation of nornicotine in tobacco. Indus, and Thgin. Chem, Analyt. Bd. 16: 377-378.

(27) Boyce, A. K. 1944. Op to now with cltras 1nsecticides. Cal1f. C1tró். 29: 117.

(18) Dashker1ch, B. B. 1934. Description of the method of preparation of a powdered insect1-funglclde. Bussian Patent 49,091, Xov. 30.

(19) - - 1939a. The chemlcal properties of commerolal anabasine sulfate. Trudy Leningrad. Inst. Sovet. Torgovl1 1939 (2): 8-13. [Abetracts in Thim. Rof. Zhur. 4 (2): 71. 194 is Chan. Ab. 37: 3228. 1943.]

(20) - - 1939b. The chloro- and bromo-subst1tuted anabasine alkalo1ds and their structure. Trudr Leningrad. Inst. Sovet. Torgovl1 1939 (2): 14-21. [Abstract in thtm. Rof. zhur. 4 (2): 47. 1941; Chem. Abs. 37: 3095. 1943.]

(21) Brmoloer, M. I. 1940. The biology of Thrips [I1ni Lad.] I1narius Oz. and control measures against 1t. [Leningrad] Inst. 2ashch Rast. (Lenin Lcad. Agr. Sc1., ए. S. S. R., Inst. Plant Prom tect.) Trudy po Zashch. Rast. (Bul. Plant Protect.) 3: 23-24, 111us. [In Russian. Abstract in Rer. Appl. Int. (A) 30: 234 235. 1942.]

(22) Ivtushenko, G. A. 1940. The most 1mportant resurts of the investigation of the physielogical section of the Tobacco and Machorka In t1 tute (WITtM). Tabakwelt 10 (6): 32-41. [In Ruseian. Abstrects in Chem. Zentbl. 112 (1): 591. 1941; Chen. Abs. 36: 7066. 1942.]

(23) Freak, 0. 1. 1942. Inseot1c1les. Chem, and Indus. 61, 429-431.

(24) Galakhor, P. N. 1941. Combat1ng the vumer cabbago 11y. Sady

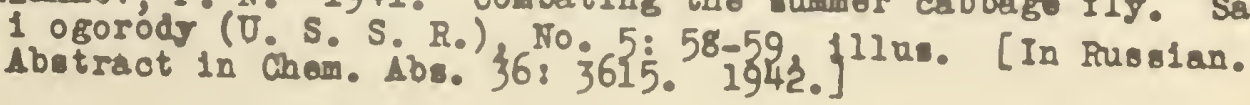


(25) Goodhue, L. D., and Sullivan, N. N. 1943. Method of apolying parasiticides. U. S. Patent 2,321,023, June 8. To Secretary of Agriculture.

(26) Haag, H. B., and Larson, P. S. 1943. Some chemical and pharmacological observations on "low nicotine" tobacco. Science 97: $187-188$.

(27) Hifbee, E. C. 1942. Insecticidal plants in the Americas. Pen Amer. Unton Bul. 76: 252-257, 11lus.

(28) Holman, H. J., ed. 1940. A survey of insecticide materials of vegetable origin. $155 \mathrm{pp}$. London. (Imperial Institute, Plant and Animal Products Dept.)

(29) Ibatulina, F.S. 1939. Testing methods for controlling the garden weevil. Plant Prot. 19: 74-92. [In Russian. Abstract in Rev. Appl. Ent. (A): 28: 128-130. 1940.]

(30) IIJin, M. 1939. Les buts et l'oriedtation des travaux de 18 section des matières prenlères vegetales de l'institut de botanique de $I^{\prime}$ académie des sclences de 1 ' URSS. Sovet Bot., No. 5: 88-94. [In Russian. Noted in Imp. Inst. Bul. [Gt. Brit.] 38: 205. 1940.]

(31) Jackson, I. I. 1941. Alkaloids of tobacco. Chem, Rev. 29: 123-197; 111us.

(32) Kabachnik, M. I., and Zitser. A. I. 1940. Amlnoanabasines. P. Aminomethylanabasines and thelr acyl derivatives. Jour. Gen. Chem. (U. S. S. R.) 10: 1007-1012. [In Russian. Abstract ib Chem. Abs. 35: 3640. 1941.]

(33) Khmura, K. F. 1939. The determination of nicotine and anabasine when present in a mixture. Vsesoluzn. Nauch. Issled. Inst. Tabach. 1 Kakhor. Promysh. [Krasnodar] [Bul.] 140: 97-102. [In Russian. Abstract in Chem, Abs. 34: 4862. 1940.]

(34) Kudryartser, A. V. 1939. The connection between the alkaloid content of Anabasis aphrlla and the blological-ecological factors. Nauch. Inst. po Udobr. 1 Inseict of unglsid Trudy. (Sc1. Inst. Fert. and Insectofunglcides Trans.), No. 135: 67-69. [In Russian. Abstracts in Khim. Ref. Zhur. 1939, No. 9: 66: Chem. Abs. 34:6325. 1940]

(35) Kuz'menko, A. A., and Tikhvinskaya, V. D. 1940. Inheritance of nicotine and anabasine content by Nicotiana tabscumNicotiana glauce hybrids and interaction of stock and scion when these species are grafted. Akad. Nauk. S. S. S. R. (Acad. des Izr. Sc1. U. R. S. S. Bul.) No. 4: [564]-575, 111us. [In Fussian. English summary, p. 576. sbstract in Chem. Abs. 35: 4801: 1941.] 
(36) Larson, P.S., and Haag, H. B. 1943. Studies on the fate of nicotine in the body. III. On the pharmacology of $80 m e$ methylated and demethylated derivatives of nicotine. Jour. Pharmacol. and Expt. Ther. 77: 343-349.

(37) -c- and Harg, H. B. 1944. Determination of nicotine and nornicotine in mixtures. Indus, and Engin. Chem., Analyt. Ed. 16: $86-90$.

(38) Lennox, F. G. 1940. Studies of the physlology and toxicology of blow-flies. 2. The action of stomach larvicides on Iucilia cuprina. Austral. Counc1l Sc1. and Indus. Res. Pam. 101: $9-49$.

(39) Leont'ev, I., and Smimora, M. 1936. Pharmacodjnamic action of the compounds of organic bases with proteins. II. Trudy po Isuchenlyu Belka Belkogo Obmena v. Organisme 9: 147-155. [In Bassian. Abstracts in Chem. Zentb1. IIO (I): 175-176. 1939: Chem. Abs. 34: 6709. 1940.]

(40) McGregor, E. A. 1943. Toxiclty of anabasine to the citrus thrips. (Scientific Note) Jour. Econ. Tht. 36: 805.

(41) -... 1943. Anabasine and Gosarol v8. citrus thrips. Calif. C1trog. 29: 3u.

(42) -n 1944. Toxiclty of anabaine to the cltrus thrips. Jour. Econ. Int. 37: 78-80.

(43) McIndoo, N. E., and Sievers, A. F. 1924. Plants tested for or reported to possess insecticidal properties. J. S. Dept. Agr. Dept. Bul. 1201, 62 pp.

(44) MaKinney, R. S. 1938. Alkaloid compound. U. S. Patent 2,139,839, Dec. 13.

(45) Markood, I. I. 1943. Quantitative determination of nicotine and nornicotine in mixtures. Assoc. Off. AET. Chem. Jour. 26: $283-289$.

(46) -..- and Barthel, W. F. 1943. Tobaccos classified according to nature of their alkaloids. Assoc. Off. Agr. Chem. Jour. 26: $280-282$.

(47) Martin, 目. 1938. Text1le or the like pestproofing medium and use. J. S. Patent $2,127,879$, sag. 23. To J. R. Geis, S. A.

(48) Nikiforov, A. 1940. Control of pests and diseases of flax and hemp. Ien 1. Konoplya 1940 (6): 45-47. [Abstracts in Shim. Ref. Zhur. 1940, No. 128 37: Chem. Abs. 37: 1219. 1943.]

(49) Cotapetz, A. P. 1940. The results of the studying of grain crop dises.8es and pests in the Voronezh reglon based on grassfield crop rotation. [Leningrad] Inst. Zashch. Rast. (Lenin Acad. Arr. Sc1., J. S. S. R., Inst. Plant Protect.), pp. 45-49. [In Pussian. Abstract in Rov. Appl. Int. (A) 29: 576. 1941.] 
(50) Patterson, N. A. 1935. Indices of toxicity for various poisons to Drosophila ampoloph1la Loew. Bnt. Soc. Ontario, Ann. Rpt. $1934: 78-80$.

(51) Pirovaror, V. H. 1940. Anabasine sulfate as a remedy against head lice, Zhur. Microblol. Bpidemil Immunoita Tsforseh, U. S. S. R., No. 4: 130-132. [In Russian. Abstracts in Chem. Abs. 36: 2084; Soap and Sanit. Chem. $18(7):$ 109. 1942.]

(52) Pleschchitser, A. Ya. 1940. Changes in the velocity of the flow of blood in the lesser circulation of rabbits after the intravenous injection of anabasine sulfate. Bul. de Biol. et Méd. Hapt. de I'U. S. S. R. 9: 446-450. [In German. Abstract in Chem. Abs. 36: 162., 1942.]

(53) Pogodina, I. A., and Sokolov, A. G. 1940. Alkaloidal fogs for combating mosquitoes. Med. Parasitol, and Parasitic Dis. 9: 109-111. [In Russian. Abstract in Chem. Abs. 36: 1422. 1942.]

(54) Poluektov, K. N. 1939. The comparative pharmacological characteristics of anabasine and of alpha-aminoanabasine. Farmakol. i Toksiko]. 2 (1): 49-5). [In Russian. Abstracts in Khim. Ref. Zhur. 1939, No. 6: 53; Chem. Abr. 34: 3818. 1940.]

(55) Razvadorski1, V.A. 1939. A comparative study of the reactions of anabasine, nicotine, and conine. Farmatsiya, No. 12: 12-15. [Abstracts in Khim. Ref. Zhur. 1940, No. 7: 38: Chem. Abs. 36: 6748. 1942.]

(56) Rekach, V. N. 1938. Cotton aphids of the south of the European part of the RSFSR. 111 pp., illus. Pyatigorsk. [In Russian. Inglish summary, po. 82-84. Abstract in Rer. Aopl. int. (A) 27: 215-216. 1939.]

(57) Reeves, E. L., Yothers, M. A., and Murray, C.W. 1939. Unusual development of apple perennial canker, following

1 application of toxic wound dressings. Phytopathology 29: 739-743.

(58) Richardson, C. E., and Smith, C. R. 1926. Toxicity of dipyridyls and certain other órganic compounds as contact insecticides. Jour. Agr. Res. 33: 597-609, illus.

(59) Richardson, H. H. 1943. Toxicity of derris, nicotine, and other insecticides to eggs of the housefly and the Angoumois grain moth. Jour. Econ. Ent. 36: 729-731.

(60) Sabinin, D. A., Baslarskaya, S. S., Beloussova, A. V., and Schocklender, G. D. 1942. New data on chemism of saline plants of Turkmania. Acad. des Sci. U. R. S. S. Compt. Rend. (Dok.) 36: 76-79. [Abstract in Chem. Abs. 37: 1473. 1943.]

(61) Sadykov, A., and Lazur'erskil, G. 1943. New method for the isolation of lupinine from technical anabasine sulfate. Jour. Gen. Chem. [U.S.S.R.] 3.3: 319-321. [Abstract in Chom. Abs. 38: 1241. 1944.] 
(62) Shmelera, M. V. 1939. Combat1ng thrips on Plax. Len 1 Konoplya Bo. 12: 20.22. [In Rassian. Abstract in Cher. Ab8. 36: 5601. 1942.]

(63) Shmuk, A. A. 1940. Changes in the alkalold contents from regetative grafting of plantB. Priroda, No. 1: 79-81. [In sosien. 1bstracts in KhIm. Ref. Zhur. 1940, Ho. 8: 36; Crem. Abs. 36: 6196. 1942.]

(Q4) --.- 1941. Identification of tobacco alkalo1ds by the athod of methrlation of thelr plcrates. Jour. 1 ppl. Chon. [O.S.S.R.] 14: 864-866. [Abstract in Chen. Ab. 37: 2135. 1943.]

(65) -... and Borordina, A. 1939. Determination of nicotine In the presence of anabasine. Jour. Appl. Chem. [0. S. 8. R.] 12: 1582-1585. [In Jrench. Abstract in Chem. Abs. 34: 7063. 1940.]

(66) -..- and Borosdina, A. 1940. A color reaction for the pyridIne ring, and the colorimetric determination of nicotine and ansbsine. Jour. Appl. Cham. [U. S. S. R.] 13: 776782. [In Musian and French. Abstract in Cholr. Abs. 35: 3035. 1941.]

(67) -..- and Borozdina, A. 1941. Alkaloide of vartous plant species within the genus N1cotians. Acad. des Scl. O.R.S.8. Compt. Rend. (Dok.) 32: 62-65. [Abstract in Chem. Abs. 37: 1012. 1943.]

(68) -... and Thmara, M. 1935. The variab1l1ty of the alkalo1d complex in hybride of several varieties of $\$ 1$ cotiana. Truad Prikl. Bot., Gonet., 1 Selek. (Bul. Appl. Bot., Genet., and Plant Breeding) (O.S.S.R.) Ser. A., No. 15 : 111-121. [Abstract in Chan. Ab8. 31: 5513. 1937.]

(69) -n Kostor, D., and Borozdira, A. 1939. Alteration in the alkalo1d compostion due to the influence of stock scion In Ilcotiane. Load, des 8c1. O. R. 8. S. Compt. Rend. (Dok.) 25: 477-480. [Abstract in Chem. 1bs. 34: 4113. 1940.]

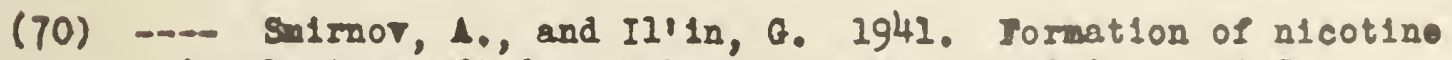
in plant grafted on tobacco. Aca1. des Sc1. O.R.S.S. Compt. Rend. (Dok.) 32: 365-368. [Abstrect in Chem. Abs. 37: 2777. 1943.]

(71) Shralkora, M. D. 1938. Microchomical detection of anabalno in local chomical invert1gatlons. Tarmatefya 1 Farmakol. 3i 10-17: [In Bonelas. Lbetracte in Chom. Zentbl. 109 (11): 4285: Chen 1bo. 34:6411. 2940.] 
(72) Smith, O.F. 1940. Toxicity of some nitrogenous bases to eggs of Iygaous kalmi1. Jour. Fcon. Int. 33: 724-727.

(73) Smith, C. R. 1942. Azeotropism in the system nicotine-meter. Separation of nicotine from related alkaloida by aquou distillation. Indus, and Fngin. Chem. 34: 251-252.

(74) Smith, H. H., and Smith, C. R. 1942. Alkalolds in cer tain species and interspecific hybrids of Nicotiana. Jour. Lgr. Rea. 65: 347-359, 111us.

(75) Sokolov, A. G. 1939a. The separation of the Anabaste aphrlia alkaloids. Nauch. Inst. po Odobr. 1 Ingektofunglsid Trudy (Sc1. Inst. Fert. and Insectofungle1des Trans.) 135: 46-51. [In Russian. Abstracts in Khin. Ref. Zhur. 1939, Ho. 9: 65: Chom. Abs. 34: 6015. 1940.]

(76) -an 1939b. Rapid methods for the determination of total alkaloid in anabasine. Nauch. Inst, po Udobr. 1 Insektofungls1d Truds (Sc1. Inst. Fert. Insectiofunglc1des Trans.) 135: 51-56. [In Pussian. Abstract in Chen. Abs. 34: 6016. 1940.]

(77) -n 1939c. The fluosilicate method for the determination of anabasino. Nauch. Inst. po Udobr. I Insaktofunglsia Truar (Sc1. Inst. Fert. Insectofungicides Trans.) 135: 57-67. [In Bussian. Abstracts in Khim. Ref. Zhur. 1939, No. 9: 65-66; Chem, $406.34: 6016,1940$.

(78) c-c 1939d. Plant polsons. Mauch. Inst. pol Udobr. In IA 7. Samollove Trans. 1919-1939, pp. 93-96: [In Ruscian. Abstracts in Khis. Reif. Zhur. 1940, No. 5: 89: Chos. 4bs. 36: 4225. 1942.]

(79) -co and Demonterik, 2. O. 1939. The diffusion process in the production of andaisine. Nauch. Inst. po Ddobr. I Insektorangl sid Truds (Sc1. Inst. Fert, and Insectofungleidos Tran.) 135: 37-46. [In Mosian. Abstract in Khin. Ref. Wher., No. 9: 65: Cher. Abs. 34:5599. 1940]

(80) -n and Koblora, I. T. 1939. Sophora as an insecticldoproduclng plant. Wauch. Inst. po Udobr. 1 Incokt; a rungl id Truds (sc1. Inst. Jort. Insectorungl cldes Irans.) 135: 148-156. [In masilan, Lbstract, in Thim. Rof. Zhar. 1939, Mo. 9: 66: Chen. 1bs. 3486001. 1940.]

(81) -c- and Trupp, P. I. 1939. The production of anubacine by tho mothod of extraction with organic solvents. Farah. Inet. po Vdobr. 1 Invaktorung old Trudr (8c1. Inst. Fort. Insectofunglcldes rrans.) 135: 25-378. [In Bussian. Lbstract in chin. Rof. Zhar., \$o. 9:65; Chen. Abs. 34; 5599. 1940.]

(82) 8path, I., Gallnorak, I., and Kavor, M, 1942. Fldo-boiline

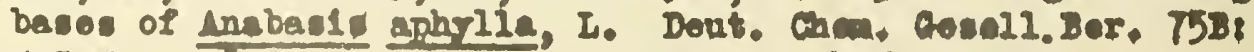
805-813. [Lbetract in Gan. 4be. 37: 3436. 1943.] 
(83) Sprenger, [C.] 1912. Pflanzengifte als Selbsthilfe gegen tlerlsche und pflanzliche schädlinge. Gartenwelt 16: 110.

(84) Steyn, D. G. 1932. Investigation 1nto the toxicity of known and unknown polsonous plant, in the Onion of South Africa. Union So. Africa Dept. Agr. Rpt. Dir. Vet. Serv, and Anim. Indus. 18: 871-891.

(85) Vickers, H. B., and Pucher, G. W. 1930. Chemlcal Invest1gat1on of tobacco. Conn. (Stato) Agr. Sxpt. Sta. Bul. 311, pp. [234]-246.

(86) Vol tenko, M. P. 1937. Hellothrips buemorrhoidal1 Boucho' and

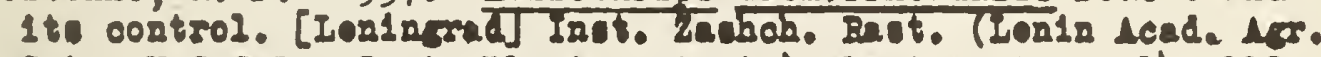
101. O.8.8.2., Inot. Plant Protoot.) Plant Protoot. 14 : 122213 [In Fuedes cbotraot in Ror. Appl. Int. (A) $26,354-355$. 1938.]

(87) Zubor, $M_{0}$, and Vasilersk11, A. 1940. The use of solbar (and ánabasin oulfato) against aphid (on cucumbers). Oroshcherodstro (o. S. S. B.) 5: 31-32. [In Russian. Abstract in Chom. Abs. 35: 5627-28. 1941.] 
